\title{
Література:
}

1. Білоусов С. Лесина пісня: повість-казка про дитинство та юність Лесі Українки. Тернопіль: Навчальна книга - Богдан, 2009. 112 с.

2. Закон України «Про освіту» № 2657-VIII від 18.12.2018. URL : http://osvita.ua/legislation/law/2231/ (дата звернення: 21.01.2020).

3. Педрада портал освітян України. Розвиток критичного мислення учнів - практичні поради. URL : https://www.pedrada.com.ua/ article/2108-11-kompetentnostey-uchnya-pochatkovo-shkoli-chek-lst-dlyavchitelya/ (дата звернення: 20.01.2020).

4. Путівник з розвитку критичного мислення в учнів початкової школи: методичний посібник для вчителів / автори-укладачі: О. І. Пометун, I. М. Сущенко. Київ, 2017. 96 с.

\section{DOI https://doi.org/10.30525/978-9934-26-041-4-65}

\section{ПІДГОТОВКА МАЙБУТНІХ УЧИТЕЛІВ ПОЧАТКОВОЇ ШКОЛИ ДО ФОРМУВАННЯ ЛОГІЧНОГО МИСЛЕННЯ УЧНІВ НОВОЇ УКРАЇНСЬКОЇ ШКОЛИ}

\author{
Григорчук Т. В. \\ аспіранта I курсу \\ Вінницький державний педагогічний університет \\ імені Михайла Коиюбинського, \\ вчитель початкових класів \\ К3 «Навчально-виховний комплекс: загальноосвітня школа \\ I-III ступенів-гімназія № 6 Вінницьккої міської ради» \\ м. Вінниця, Украӥна
}

За даними досліджень вітчизняних вчених - Г.О. Балла, Л.С. Виготського, Ю.З. Гільбуха, В.В. Давидова, О.К. Дусавицького, Д.Б. Ельконіна, Г.С. Костюка, С.Д. Максименка, В.О. Моляко, С.Л. Рубінштейна, .В. Скрипченка, Ю.М. Швалба, - розвиток мислення є одним з основних завдань навчальної діяльності.

Аналіз спеціальної літератури дозволив виявити, що поняття «логічне мислення» почало формуватися 3 давніх часів, коли і було закладено структуру міркувань, понять, умовиводів, яка використовується на сучасному етапі розвитку науки і суспільства в цілому. Загальні положення представлених теорій $є$ своєрідним сплавом 
філософських, психологічних, педагогічних, логічних, соціологічних, історичних, кібернетичних аргументів, який практично неможливо розділити [1, с. 178].

Сучасні тенденції розвитку науки дають підстави розглядати мислення як вищу форму відображення дійсності в психіці, ідеальну діяльність, результатом якої є об'єктивна істина. Мислення виникає i розвивається разом із практичною діяльністю людини на основі чуттєвого пізнання. Воно дає можливість не лише дізнатися про певні факти і явища, а й зрозуміти причини їх існування, передбачити майбутні події. Мислення тісно пов'язане з мовленням і має суспільноісторичний характер [3, с. 220].

3 огляду на розвиток поняття « логічного мислення « та на основі досвіду практичної діяльності виокремлюють загальні критерії розвитку логічного мислення: рівень володіння логічними операціями (порівняння, аналіз, синтез, абстрагування, узагальнення); рівень володіння логічними уміннями (визначення і використання понять, здійснення умовиводів, встановлення причинно-наслідкових зв'язків між фактами, процесами, явищами відповідно до законів логіки, рівень уміння організовувати вихідні та обгрунтовуючі дані, оцінювати їх та результати розв'язування задачі). Логічне мислення передбачає наявність таких складників: уміння орієнтуватися на суттєві ознаки об’єктів і явищ, уміння підкорятися законам логіки, організовувати свої дії відповідно до цих законів, уміння робити логічні операції, свідомо їх аргументувати, уміння будувати гіпотези і робити наслідки із даних посилань [2, с. 380].

Аналіз наукової літератури стосовно проблеми розвитку логічного мислення учнів дає змогу виділити серед інших підходів такі: прагнення відійти від формалізації системи навчання (Ю.О. Петров, О.В. Тягло); оволодіння логікою - об'єктивним продуктом суспільної практики людства (О.М. Леонтьєв, Н.А. Підгорецька); спеціальне навчання логічним прийомам (І.В. Істоміна, О.М. Кабанова-Меллер, В.І. Решетніков, М.М. Шардаков); зв'язок формування логічних умінь 3 розвитком пізнавального інтересу до предметів природничоматематичного циклу, 3 формуванням логічної культури (М.В. Богданович, О.С. Дубінчук); використання спеціально підібраної системи пізнавальних задач i завдань 3 логічним навантаженням (В.I. Загвязинський, I.Я. Лернер, О.І. Федоренко); застосування системи диференційованого підходу в навчальному процесі (І.М. Осмоловская, I.E. Унт); врахування індивідуально-психологічних особливостей у процесі організації навчальної діяльності школярів, урахування рівня підготовки й типу мислення (Ш.А. Амонашвілі, Ю.К. Бабанський, Т.М. Овчинникова) [6, с. 204]. 
Результати вивчення наукової літератури свідчать, що за наявності великої кількості праць, присвячених розвитку логічного мислення учнів, дотепер недостатньо уваги приділяється дослідженням зв'язку «розвиток особистості - розвиток мислення», без якого неможливе знання, розуміння і застосування тих самих операцій логічного мислення, про які йшлося вище. Прийом може мати значення для розумового розвитку лише тоді, коли учень свідомо засвоїть його, що, на наш погляд, можливо за умови особистісної цінності цього прийому для даного учня. Лише ті нові знання та навички, які проходять через призму особистісного досвіду і залишаються в цьому досвіді як особистісно значущі, будуть сприяти розвитку мислення учнів.

Отже, існують особистісні (внутрішні) умови, оскільки мислення не існує само по собі, - воно властиве живій людині з іiі особистим досвідом, індивідуальними особливостями, активністю, нахилами, прагненнями. Внутрішні умови мислення роблять його вольовим, цілеспрямованим і натхненним процесом. Таким чином, весь процес мислення і здобування нових знань відбувається в нерозривній єдності внутрішніх i зовнішніх умов, ефективному розвитку якого сприяє особистісно орієнтоване навчання [4, с. 240].

Навчання $є$ провідною діяльністю у початкових класах, тому саме молодший шкільний вік має великі резерви формування мислення учнів. Зусилля науковців та практиків сьогодні спрямовані на пошуки нових організаційних і змістовних компонентів навчальної діяльності, за яких відбувається розвиток мислення молодших школярів та оптимізується навчально-виховний процес. Аналіз науковопсихологічної літератури свідчить, що розвиток мислення являє собою складне явище, яке характеризується цілою сукупністю рис i обумовлене рядом причин: змістом знань, методами (О.М. КабановаМеллер, Н.О. Менчинська); розвиток мислення дитини не можна розглядати у відриві від іiі психічного розвитку в цілому, від багатства інтересів дитини, іiі почуттів і всіх інших складових, які утворюють іii духовний склад (3.І. Калмикова); розвиток мислення являє собою складну динамічну систему кількісних та якісних змін, які відбуваються у мисленнєвій діяльності людини у зв'язку з її віком і збагаченням життєвого досвіду (Б.Г. Ананьєв).

Кардинальні зміни в освіті зумовили прийняття Концепції «Нова українська школа та Державного стандарту початкової школи (2018р.), у яких визначені вимоги до якості навчання учнів та способи їх реалізації в загальноосвітній школі. Це вимагає змін у системі підготовки майбутніх педагогів, зокрема у підготовці майбутніх учителів початкової школи до формування логічних умінь в учнів. Адже інтелектуальний розвиток дітей сприяє можливості та якості 
засвоєння нових знань. Володіння прийомами розумових операцій допомагає легше сприймати різну інформацію, розвиває уяву, полегшує спілкування, виконання вправ, практичних робіт, розв'язування задач, покращує самостійну роботу з книгою на занятті та при виконанні домашніх завдань. Погано розвинена пам'ять, відсутність вміння аналізувати, порівнювати, виділяти головне заважають дитині повноцінно сприймати й розуміти навчальний матеріал $[5$, с. 80].

Тому завданням сучасних учителів $є$ розвиток логічного мислення учнів, що сприятиме формуванню у них логічних умінь. Логічне мислення не $\epsilon$ вродженим, тож його можна і потрібно розвивати.

Отже, підготовка майбутніх учителів до формування логічних умінь учнів початкової школи - це педагогічний процес, який передбачає набуття майбутніми фахівцями знань із логіки та методики формування логічних умінь у молодших школярів, практичного досвіду оперувати та застосовувати основні логічні закони для розв'язування різних типів логічних завдань, навичок викладання предмета «Логіка» в початковій школі, що $\epsilon$ необхідними для формування логічних умінь молодших школярів.

\section{Література:}

1. Арделян О. В. Дидактичні умови формування загально пізнавальних умінь і навичок у молодших школярів (на матеріалі вивчення англійської мови: дис. ... канд. пед. наук. Кіровоград, 2002. $227 \mathrm{c}$.

2. Будник О. Б. Професійна підготовка майбутніх учителів початкових класів до соціально-педагогічної діяльності: ди с. ... докт. пед. наук. Житомир, 2015. 552 с.

3. Коваль Л. В. Професійна підготовка майбутніх учителів у контексті розвитку початкової освіти: монографія. Донецьк, ЛАНДОН-ХХІ, 2012. 343 с.

4. Мозуль I. Проблема готовності майбутніх учителів до професійної діяльності в умовах модернізації змісту початкової освіти. Науковий вісник МНУ імені В. О. Сухомлинського. Педагогічні науки. 2016. № 1(52). С. 238-242.

5. Ящук О. М. Критерії підготовки майбутніх учителів до формування логічних умінь. Неперервна педагогічна освіта в Україні: стан, проблеми та перспективи: матеріали Всеукр. наук.-практ. Інтернет- 212 конф. (Умань, 27 квіт. 2018 р.). Умань, 2018. С. 80-82.

6. Ящук О. М. Основні поняття логіко-математичного мислення особистості. Психолого-педагогічні проблеми сільської школи. Умань, 2015. Вип. 53. С. 203-208. 